\title{
THE DEBT PROBLEM OF PIIGS COUNTRIES AND RECOVERY MECHANISMS BUILT AT THE MONETARY UNIT LEVEL
}

\author{
DOI: 10.17261/Pressacademia.2020.1208 \\ JEFA- V.7-ISS.2-2020(5)-p.120-133
}

\section{Cagdas Bektas', Ozgur Sarac ${ }^{2}$}

'Dokuz Eylul University, Master of Public Finance Program, Izmir, Turkey.

cagdasbektas@gmail.com, ORCID: 0000-0001-6355-0139

${ }^{2}$ Dokuz Eylül University, Faculty of Economics Administrative Sciences, Department of Public Finance, Izmir, Turkey. osarac1973@gmail.com , ORCID: 0000-0001-8029-6646

\begin{tabular}{ll}
\hline Date Received: April 8, $2020 \quad$ Date Accepted: June 18, 2020
\end{tabular}

To cite this document

Bektas, C., Sarac, O. (2020). The debt problem of PIIGS countries and recovery mechanism built at the monetary unit level. Journal of Economics, Finance and Accounting (JEFA), V.7(2), p.120-133.

Permanent link to this document: http://doi.org/10.17261/Pressacademia.2020.1208

Copyright: Published by PressAcademia and limited licensed re-use rights only.

\begin{abstract}
Purpose - Using the data of the last 20 years of PIIGS countries' budget deficit and debt burdens in the period before the Covid 19 epidemic, this study presents a chronological set of information about the measures taken at the monetary union level in the face of debt problems and aims to contribute to the discussions about the future of the EU from the perspective of public finance

Methodology - In the study, the financial support mechanisms of the EU were discussed and the financial performances of PIIGS countries were examined based on budget deficit and debt burden data indexed to GDP from the pre-monetary union period to today, between 19982018.

Findings- Budget deficits of PIIGS countries have been reduced to reference values, but debt burdens have increased even more than the pre-crisis period. The support provided by the Union to these countries did not solve problems, and postponed them. Both the monetary union and PIIGS countries need comprehensive reforms.

Conclusion- The financial problems of PIIGS countries became more severe after the 2008 global crisis and turned into a European Debt Crisis in 2011. Various measures were taken at the European Union (EU) level in the face of the 2011 Debt Crisis. The expected gains from these measures, called "rescue packages" in the public, have not been achieved. The serious financing problem and public finance problems that have not been solved for a long time have become more clearly threatening the future of the EU.
\end{abstract}

Keywords: PIIGS countries, budget deficits, debt crisis in 2011, fiscal consolidation, dept criteria.

JEL Codes: E60, F34, H63

\section{PIIGS ÜLKELERININ BORÇ SORUNU VE PARASAL BÍRLIK DÜZEYINDE OLUŞTURULAN KURTARMA MEKANIZMALARI}

\section{ÖZET}

Amaç - Covid 19 salgını öncesi dönemde PIIGS ülkelerinin bütçe açığı ve borç yüklerine ait son yirmi yılın verilerini kullanan bu çalışma, yaşanan borç sorunları karşııında parasal birlik düzeyinde alınan tedbirler hakkında kronolojik bir bilgi seti sunmakta ve $A B^{\prime}$ nin geleceği hakkındaki tartışmalara kamu maliyesi perspektifinden katkılar sağlamayı amaçlamaktadır.

Yöntem - Çalışmada AB'nin mali destek mekanizmaları ele alınmış ve PIIGS ülkelerinin parasal birlik öncesi dönemden günümüze 1998-2018 yılları arası GSYH'ya endeksli bütçe açığı ve borç yükü verileri üzerinden mali performansları incelenmiştir.

Bulgular- PIIGS ülkelerinin bütçe açıkları referans değerler düzeyine çekilmiş ancak borç yükleri kriz öncesi döneme göre daha da artmıştır. Birliğin bu ülkelere verdiği destek sorunları çözmemiş, ertelemiştir. Hem parasal birliğin hem de PIIGS ülkelerinin kapsamlı reformlara ihtiyacı bulunmaktadır.

Sonuç- PIIGS ülkelerinin mali sorunları, 2008 küresel krizi sonrasında daha da ağırlaşmış ve 2011 yllında Avrupa Borç Krizine dönüşmüştür. 2011 Borç Krizi karşııında Avrupa Birliği (AB) düzeyinde çeşitli tedbirler alınmıştır. Birlik kamuoyunda "kurtarma paketleri” olarak adlandırılan bu tedbirlerden beklenen kazanımlar sağlanamamıștır. Ortaya çıkan ciddi finansman sorunu ve uzun zamandır çözülemeyen kamu maliyesi sorunları, $A B^{\prime}$ nin geleceğini çok daha açık şekilde tehdit eder hale gelmiştir.

Anahtar Kelimeler: PIIGS ülkeleri, bütçe açı̆̆ı, 2011 mali krizi, mali konsolidasyon, borç kriteri. JEL Kodları: E60, F34 H63 


\section{GiRiş}

Bir iktisadi entegrasyon girişimi olan Avrupa Birliği (AB), gelişmiş ülkelerin öncülüğünde uzunca bir süreçten geçmiş ve çeşitli aşamaları başarı ile atlamış bir ortaklıktır. Günümüzde yirmi yedi üyeden ${ }^{1}$ oluşan bu ortaklık içinde bir de ortak para birimi Euro'yu kullanan on dokuz üyeli bir parasal birlik vardır. 4,2 milyon $\mathrm{km}^{2}$ yüzölçümü ve 400 milyonu aşan nüfusu ile çok kültürlü ve kozmopolit bir yapıya sahip olan AB, ekonomik açıdan tam bir devdir. Öyle ki, 2018 yılı itibariyle AB'nin GSYH'si 18,7 trilyon dolardır. Bu ekonomik çapıyla AB, 20,5 trilyon dolarlık Amerika Birleşik Devletleri'nin (ABD) ardında ve 13,6 trilyon dolarlık Çin'in önünde ikinci sıradadır (Dünya Bankası, 13 Şubat 2020). AB, dünya mal ihracatında yüzde 15,2 ve ithalatında yüzde 14,7 paya sahiptir. Birlik, hizmet ticaretinde de 210 milyar dolar ticaret fazlasıyla dünyanın en büyük ihracatçısı konumundadır (TCTB, 3 Ekim 2019).

$A B$ kurulduğu 1958 yılından bu yana ekonomik, sosyal ve çevresel konularda işbirliğini hedeflemiştir. Bunların yanı sıra ortak dışişleri ve güvenlik politikasının oluşturulması ile adalet ve suça karşı işbirliği de $A B^{\prime}$ nin amaçları arasındadır. Tarihsel süreçte bu amaçlara yönelik çeşitli zirveler yapılmış ve imzalanan anlaşmalar sayesinde bağlayıcı kurallar oluşturulmuştur. Kuralların sağladığı kazanımlar, Birlik için nihai amaç olan siyasi entegrasyon olma yolunu ilerletmektedir. Lakin bütünleşme çabaları tarihsel süreçte ciddi şekilde aksamıştır. 2008 yılında yaşanan küresel krizle Birliğin bir numaralı meselesi haline gelen sorunlu mali yapı, bu aksaklıklardan belki de en ciddi olanıdır.

Küresel krizin getirdiği sorunlar özellikle parasal birlik ülkelerinde kamu maliyesi sorunlarının ağırlaşıp ciddi boyutlara ulaşmasına sebep olmuştur. Önceleri Yunanistan'da ortaya çıkan borçlanma sorunu, kısa zamanda -sonradan PIIGS2 ülkeleri olarak adlandırılacak olan- Portekiz, İrlanda, İtalya ve İspanya'ya sıçramış ve 2011 yılında Avrupa Borç Krizine dönüşmüştür.

Birlik bünyesinde oluşturulan kurtarma paketleri ve bunlar sayesinde sağlanan borç ötelemeleri, krize karşı alınan tedbirlerin başında gelmektedir. Lakin yaşanan borç krizi uluslararası kamuoyunda Euro ve Parasal Birliğin geleceği hakkında ciddi endişelere neden olmuştur. Yaşanan kriz Birlik içerisinde var olan Kuzey-Güney ayrışmasını belirginleştirmiştir. Ayrıca bu dönemde büyük ortaklardan biri olan Britanya'nın AB'den çıkma kararı alması ve 2020 yılı başında Birlikten ayrılması, oluşan endişeleri daha da arttırmış ve " $A B$ dağılıyor mu?" sorusunu gündeme getirmiştir.

Çalışmamızın odağını oluşturan PIIGS ülkeleri $A B$ içerisinde sorunlu Güneyi temsil etmektedir. AB'nin zayıf karnını oluşturan bu ülkeler yaşadıkları mali sorunlar nedeniyle $A B$ ve özelde Parasal Birliğin geleceğini doğrudan etkiler bir konumdadırlar.

Covid 19 Küresel Salgını öncesi PIIGS ülkelerinin mali durum ve performanslarına odaklanan çalışmada konu ile ilgili literatür taraması yapılarak ilk önce 2011 Avrupa Borç Krizi ele alınacak ve krizin yaşanmasına neden olan unsurlar değerlendirilecektir. İkinci olarak borç krizine karşı Birlik bünyesinde oluşturulan finansman mekanizmaları incelenecek ve bu kapsamda alınan tedbirler detaylandırılacaktır. Üçüncü olarak ise PIIGS ülkelerine ait kamu maliyesi performansları ele alınarak 1998-2018 yıllarına ait -her ikisi de Maastricht Kriterleri arasında yer alan- bütçe açıkları ile borç yükleri (borç stoklarının GSYH'ye oranları) incelenerek bu ülkelerin mali açıdan yaşadıkları sorunun mevcudiyeti ortaya konacaktır. Sonuç bölümünde ise, finansal kurtarma sürecinin PIIGS ülkeleri açısından bir çözüm olup olmadığı ile ilgili değerlendirmeler yapılacak ve mevcut mali durum ve bu duruma karşı Birlikçe takınılan tutum karşısında Avrupa Birliğinin geleceğine dair öngörülerde bulunulacaktır.

\section{LITERATÜR TARAMASI}

Kriz öncesi ve sonrası dönemde PIIGS ülkelerinde var olan mali problemlerin tespiti ve çözümüne yönelik yapılan çalışmalarda görülmektedir ki PIIGS ülkeleri parasal birliğin en başından beri AB'nin standartlarına ve değişen koşullarına ayak uydurmakta güçlük çekmektedir.

Kibritçioğlu (2011) parasal birliğin bir optimum para sahası oluşturmadığını, özellikle Birlik içerisinde emek faktörünün yeterince akışkan olmadığına dikkat çekmektedir. Birbirinden farklı koşullara sahip ülkelerin ortak bir para politikası uygulamaktaki güçlüklerine dikkat çekerek PIIGS ülkelerinin Euro Bölgesine katılarak borçlanma maliyetlerinin suni olarak azaldığına dikkat çekmektedir.

Samuel (2020) PIIGS ülkelerinin mali yapılarındaki bozulmada düşük maliyetli borçlanabilmelerinin etkisine dikkat çekmiş, 2013-2018 yılları arası yaşanan, İrlanda hariç tutulursa, kısmi toparlanmanın yeterli olmadığını ifade ederek bu ülkelerin mevcut parasal birliğin koşullarına alternatif şartlarda mali yapılarını toparlayabileceklerini savunmuştur.

Siemiatkowski ve Jankowska (2013) yaptıkları çalışmada PIIGS ülkelerinin hem kamu hem de özel sektör göz önüne alındığında finansal olarak dışa bağımlı olduğu sonucuna varmıştır. Bağımlı ekonomiler kendi makro ekonomik göstergeleri üzerinde söz

${ }^{130}$ Ocak 2020 tarihi itibariyle Britanya, Avrupa Birliği'nden resmen ayrıımıştır.

2ingilizce "domuzlar" anlamına gelen ve küçümser niteliği nedeniyle kınanan bu kısaltma, iktisadi ve mali literatürde sıkça kullanılan bir kısaltmadır. Avrupa Parasal Birlik üyeleri arasında yüksek mali kırılganlığa sahip dört ülkenin -Portekiz, İtalya, Yunanistan ve İspanyasıralamasından oluşan PIGS kısaltması, sonradan sergilediği kötü mali performans sebebiyle îrlanda'nın da eklenmesiyle PIIGS'e dönüşmüştür. 
sahibi olamamaktadır. Bu nedenle PIIGS ülkelerinin içinde bulunduğu bağımlı mali yapı Parasal Birliği sürekli olarak tehdit etmektedir.

Duman (2017) PIIGS ülkelerindeki ekonomik krizin nedeninin sadece kuralsız ve aşırı finansallaşmaya bağlı olmadığını, Euro Bölgesi ekonomileri arasındaki iktisadi ve ticari dengesizliklerin ve bu ülkelerde reel ekonomi ile finansal ekonomi arasındaki kar uyumsuzluğunun krizde etkili olduğunu savunmaktadır.

Gümüş ve Tatlıyer (2013) Portekiz, İspanya, İtalya ve Yunanistan'ın yıllar içerisindeki sosyal harcama artışlarını mevcut mali durumları ile ilişkilendirmiştir. Çalışmada bu ülkelerin içerisinde bulundukları mali zorlukların gelir düzeyleri ile orantısız bir şekilde yapmış oldukları sosyal harcamalar nedeniyle oluştuğunu savunmuşlardır. Çalışmaya göre Güney Avrupa Ülkeleri ekonomik büyüme ve rekabetçilik açısından Kuzeyi yakalayamamakta buna karşın Avrupa standartlarında bir sosyal refah devletini sürdürmeye çalışmaktadırlar. Mevcut durumda bu ülkeler giderek artan borç yükleri ve üzerlerine almış oldukları sosyal sorumluluklar arasında sıkışmışlardır.

Şeker, Demirel ve Eroğlu (2016) AB'nin temel probleminin ekonomik büyümede olduğunu, bu sorunu aşmak için Birliğin ortak bir maliye politikası bulunmadığı ve mali açıdan sorun yaşayan ülkelerin yüksek kamu borç stokları nedeniyle kullanabilecekleri maliye politikası imkanlarının sınırlı olduğu hatırlatmasını yaparak $A B$ için çözümün para politikası uygulaması ve yapısal reformlar olduğunu savunmaktadır.

Krugman (2012) büyüme sorununun çözümü ile ilgili olarak Avrupa Merkez Bankasının (AMB) genişletici para politikası uygulayarak Almanya gibi zengin Kıta Avrupası ülkelerinde ılımlı seviyede enflasyon yaratabileceğini, bu politikanın Kıta Avrupası Ülkelerinin verimlilik düzeyini düşürerek dolaylı yoldan Güney Avrupa Ülkelerinin verimlilik düzeyini arttıracağını savunmuştur (Krugman, 2012, s. 179). Ancak AMB, Almanya'nın da etkisiyle enflasyon konusunda tavizsizdir. Bu nedenle ortak para Euro değer kazandıkça PIIGS Ülkelerinin rekabet gücü ve dolayısıyla büyüme oranları azalmaktadır.

PIIGS Ülkeleri ve Türkiye'de kamu borçlarının ekonomik büyümeye etkisini inceleyen Bölükbaş M., Bölükbaş T. ve Topal (2018) PIIGS ülkelerinin 1960-2015 yılları verilerini kullanarak yaptıkları zaman serisi analizine göre İtalya haricinde diğer ülkelerde kamu borç yükündeki artışların uzun dönem ekonomik büyüme performansını olumsuz etkilediği sonucuna ulaşmıştır. ${ }^{3}$

Bergsten (2012) Avrupa krizinin kökeninin parasal birliğin hatalı kurumsal dizaynı olduğunu savunmaktadır. Parasal birlik oluştururken Birlik ve ortak para birimi sadece AMB'ye emanet edilmiştir. Parasal Birlik kurulurken üye ülkeler arasında tam olarak ekonomik, mali birlik sağlanamamış ve birlik içerisinde bankacılık ve finans sektöründe birlik oluşturulmamış, ortak ekonomik yönetim kurumları ve yapısal ekonomi politikalarının anlamlı bir koordinasyonu sağlanmamıştır. Parasal Birliğin mimarları birlik içerisinde tam ekonomik bütünleşmenin Parasal Birliği takip edeceğini varsaymışlardır. Ancak yaşanan krize kadar AB ülkeleri bu konuda bir baskıyla karşılaşmamış ve dolayısıyla kapsamlı adımlar atmamışlardır. Bu nedenle kriz vurduğunda $A B$ krize karşı kullanabileceği önemli politika araçlarından yoksundur. Yine Bergsten (2012) göre kriz karşısında $A B$ 'nin iki seçeneği bulunmaktadır. Ya parasal birlikten safra atılacak yani Yunanistan gibi ülkeler parasal birlikten çıkarılacak yada ekonomik entegrasyon tamamlanacaktır. Ancak ne Almanya ne de AMB krizi hızlı bir biçimde çözmeye çalışmamıştır. Krizi uzun vadede güçlü bir Avrupa ekonomisi oluşturmak için gereken ekonomik reformları ilerletmek için bir fırsat olarak görmüşlerdir. Oluşturulmaya çalışılan bu baskı Euro Bölgesi otoritelerinin neden piyasaların arzuladığı kadar büyük bir kurumsal finansal önlem almadıklarının açıklamasını oluşturmaktadır (Bergsten, 2012:16-17). Söz konusu durum bu günün koşulları için de geçerlidir.

\section{KÜRESEL KRIZIN PIIGS ÜLKELERI ÜZERINDEN YANSIMASI: AVRUPA BORÇ KRIZi}

Krizlerin birbirlerine entegre ekonomileri çok hızlı etkilediği, su götürmez bir gerçektir. Bu nedenle, ana hatlarını küreselleşmenin şekillendirdiği günümüz krizlerinin sirayet etkilerinin geçmiş krizlere göre çok daha güçlü olması ve bu krizlerin çok daha geniş bir alana yayılması muhtemeldir. Öyle ki, bundan böyle yaşanacak krizlerin belki de tamamı "küresel" vurgusu ile anılacaktır. Nitekim 2008 krizi, gelişmiş ülkeleri çok hızı bir şekilde etkileyen ve sonrasında etkileri, tüm dünyaya yayılan küresel bir kriz olmuştur. Entegrasyon sürecini kesintiye uğratan bu krizin AB'deki karşılığı -PIIGS ülkeleri üzerinden okunduğunda- bariz bir borç krizidir. Lakin yaşanan borç krizi, PIIGS ülkeleri ile sınırlı değildir. Bu ülkeler ortak para birimi Euro'yu kullanmaları sonucu borç ilişkilerini Euro cinsinden kurdukları için yaşadıkları krizi, AB'nin üst oluşumu olan Parasal Birliğe bulaştırma ihtimalleri oluşmuştur. Geçmişte Yunanistan örneğinde olduğu üzere, kriz ölçeğinin bu seviyeye yükselmesi ise $A B^{\prime}$ nin bugüne kadar sağladığı kazanımları anlamsız kılacak ve belki de gelecekte $A B$ sürecinin tümden tıkanmasına sebep olacaktır.

2008 Küresel Ekonomik Krizinin gelişmiş ekonomiler açısından ilk etkisi, iktisadi küçülme olmuştur. 2009 yılında yüzde 3,4 küçülen gelişmiş ekonomiler içinde en fazla etkilenen ülke grubu $A B$ ülkeleri olmuştur. Öyle ki, bu dönemde Euro Bölgesi

\footnotetext{
${ }^{3}$ Yüksek borç seviyelerinin ekonomik performansa olumsuz etkisi sadece PIIGS ülkeleri ile sınırlı değildir. 1960 ile 2012 yılları arası gelişmiş ve gelişmekte olan 118 ülkeyi inceleyen bir araştırma, yüksek borç seviyeleri ile ekonomik performans üzerindeki uzun vadeli olumsuz etkiler arasındaki bağlantıyı doğrulamaktadır (Eberhardt ve Presbitero, 2015).
} 
yüzde 4,1 küçülerek kendi tarihinin en büyük daralmasını yaşamış (Yılmaz, 2013: 58-59) ve ciddi borç sorunu yaşayan PIIGS ülkeleri sebebiyle $A B$, küresel gündemin ve küresel krizin merkezi aktörü statüsüne yükselmiştir. PIIGS Ülkelerinin yaşadıkları borç sorunu, ülkelerin kredi derecelendirme puanlarına hızla yansımış ve $A B$ ülkelerinde borçların sürdürülebilirliği prestij kaybının ötesinde ciddi endişeleri de beraberinde getirmiştir.

Grafik 1: PIIGS Ülkelerinin Kredi Notlarının Seyri, 1998-2020

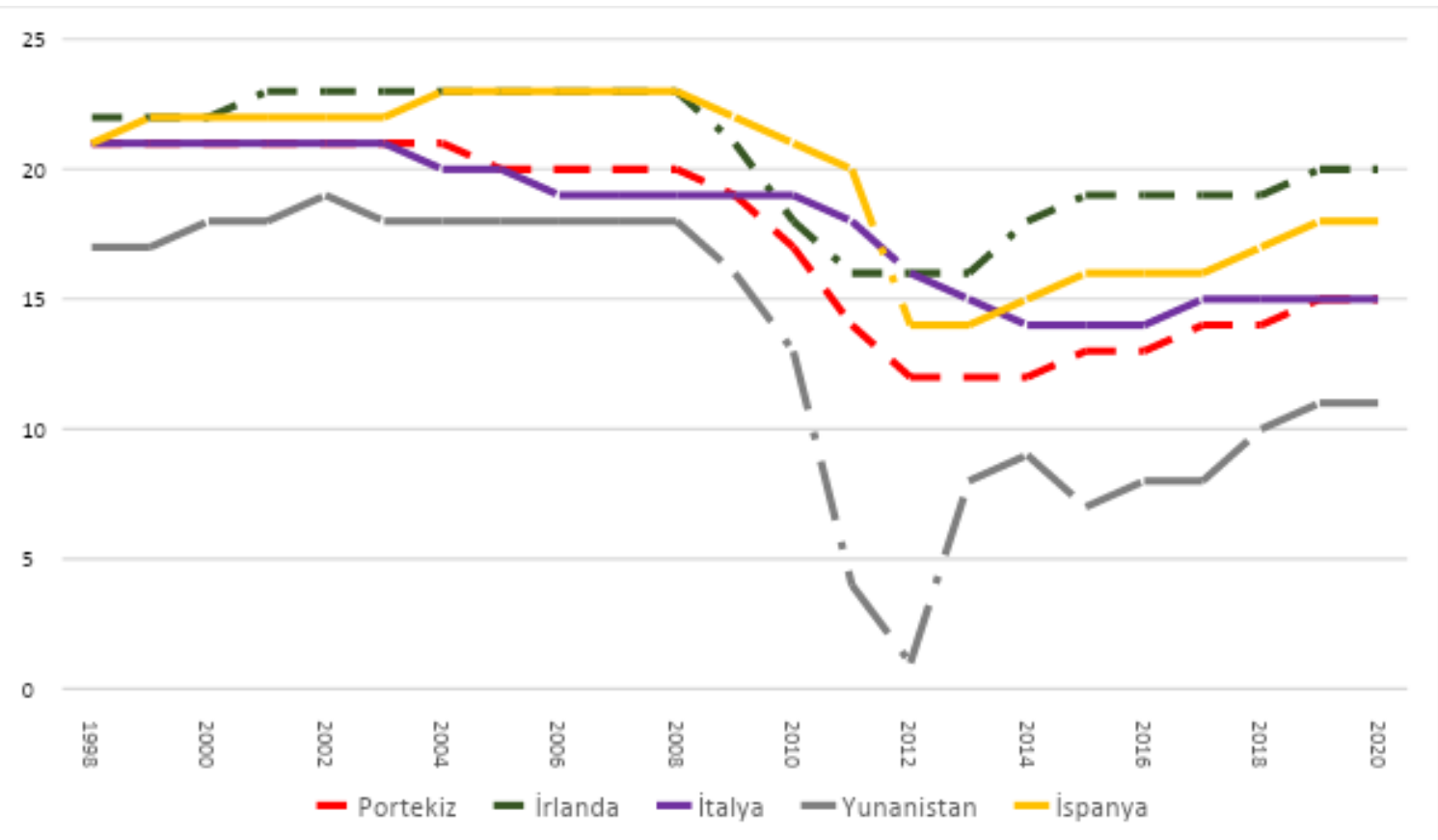

Kaynak: http://worldgovernmentbonds.com verileri kullanılarak tarafımızca düzenlenmiştir ${ }^{4}$ (02 Mart 2020).

Grafik 1'de görüldüğü üzere küresel kriz öncesinde oldukça yüksek, hatta PIIGS ülkelerinden İrlanda ve İspanya için "Maksimum Güvenlik" anlamına gelen AAA puanı ile Yunanistan için "Üst Orta Sınıf Güvenlik" anlamına gelen A puanı arasında değişen derecelendirmeler PIIGS ülkeleri için 2008 Kriziyle birlikte toplu bir şekilde düşmeye başlamıştır. Öyle ki, kredi notundaki düşüş İrlanda, İtalya ve İspanya için "Düşük Orta Sınıf Güvenlik" seviyesine gerilerken Portekiz için "Spekülatif Seviye", Yunanistan içinse "Yükümlülüğünü Yerine Getiremez" seviyesine inmiştir5. 2012 yılından sonra nispeten toparlanmalar olsa da PIIGS ülkelerinin kredi notları, Parasal Birlik üyesi diğer ülkelerden daha düşük kalmıştır. Bu durum PIIGS Ülkeleri için daha maliyetli re-finansman anlamına gelirken, AB'yi domine eden Almanya ve Fransa için ise hem bir prestij kaybı hem de çözüm bulma çabalarının kendilerinde yoğunlaşması anlamına gelmiştir.

PIIGS ülkeleri ortak para birimi olan Euro'yu kullandıklarından ve Euro'nun kontrolü AMB inisiyatifinde olduğundan PIIGS ülkeleri vadesi gelen borçlarını emisyon yoluyla finanse edememiş ve borcu borçla finanse etme yoluna gitmişlerdir. Bu ise borçların sürdürülebilirliğini tehlikeye sokmuştur. Anılan dönemde Euro'nun dolar karşısında değerlenmesi sebebiyle $A B$ ülkelerinin üretim ve ihracatı istenilen seviyeye ulaşamamıştır. Hal böyle olunca PIIGS ülkeleri artan borçlarını çevirmekte zorlanmıştır. Bu ise PIIGS ülkelerine ait tahvilleri elinde tutan yatırımcıları kaygılandırmış ve Parasal Birlik üyesi olan tüm ülkelere ait tahvillerin de benzer şekilde güvenli olmadığını açığa çıkarmıştır (Beker, 2014: 1). O dönemde ABD’nin borç tavanını artırması ve ülke tarihinde ilk defa kredi notunun düşürülmesi, piyasalardaki olumsuz beklentileri daha da arttırmıştır. Bu gelişme karşısında zaten zor durumda olan PIIGS ülkelerinin borçlanma maliyetleri çok daha fazla yükselmiş ve bu ülkeler borç krizine sürüklenmiştir. Kısacası küresel krizin etkileri, Avrupa ülkeleri için borç krizini tetiklemiştir. Yaşanan borç krizi karşısında hiç de şaşırtıcı olmayan bir şekilde Almanya ve Fransa öncülüğünde birlik bünyesinde çözümler üretilmeye

${ }^{4}$ Kullanılan değerlerin Standard and Poor's kurumundaki harf karşılıkları ve açıklamaları şöyledir; (23: AAA) Maksimum Güvenllik, (22: AA+, 21: AA, 20: AA-) Yüksek Sınıf Güvenlik, (19: A+, 18: A, 17: AA-) Üst Orta Sınıf Güvenlik, (16: BBB+, 15: BBB, 14: BBB-) Düşük Orta Sınıf Güvenlik, (13: BB+, 12: BB, 11: BB-) Spekülatif Seviye, (10: B+, 9: B, 8: B-) Yüksek Spekülatif Seviye, (7: CCC+, 6: CCC, 5: CCC-) Şiddetli Risk, (4: CC) Aşırı Spekülatif Seviye, (3: C, 2: RD, 1: SD, 0: D) Yükümlülüğünü Yerine Getiremez.

${ }^{5}$ Parasal Birlik üyesi bir ülkenin kredi notunun “Yükümlülüğünü Yerine Getiremez" seviyeye gerilemesi, o dönemde dikkatlerin Yunanistan'da toplanmasına sebep olmuştur. Öyle ki, birçok akademik çalışmada Avrupa Borç Krizi görmezden gelinmiş ve sorun, sadece Yunanistan borç sorunu olarak ele alınmıştır. 
çalışılmış, lakin kısa dönemde elle tutulur bir başarı sağlanamamıştır. Artan çözümsüzlük ve oluşan finansman sorunu, o dönemde fazlasıyla büyümüş ve $A B^{\prime}$ nin üçüncü büyük ekonomisi olan Britanya, Avrupa Birliğinden ayrılma kararı almıştır.

\section{BíRLIK BÜNYESINDE OLUŞTURULAN KURTARMA PAKETLERI VE ALINAN TEDBIRLER}

AMB ortak para birimi olan Euro üzerinde tam inisiyatif sahibidir. AMB'nin sahip olduğu bu yetki, onu parasal birliğin para politikasını şekillendiren organ konumuna yükseltmektedir. Parasal birlik üyesi ülkelerin münferit olarak izleyecekleri para politikaları yoktur. Hal böyle olduğundan PIIGS ülkelerinin yaşadıkları borç krizleri karşısında alınacak parasal tedbirler ulusal düzeyde değil, birlik düzeyinde olmak zorundadır. Lakin bu aşamada şu husus önem kazanır: AMB'nin PIIGS ülkelerine yönelik tedbirleri, borç sorunu olmayan ülkeleri nasıl etkileyecektir? Örneğin finansman sağlamaya yönelik genişletici bir politika, bir tarafta "sorun çözümü" olurken diğer tarafta "sorun sebebi" olabilir. İrlanda ve Almanya gibi farklı ekonomik büyüklük ve şartlara sahip ülkelerin yer aldığı parasal birlikte tüm üyelere uygun bir para politikası izlenmesi mümkün değildir (Dinan, 2008: 372). Ayrıca AMB'nin karar alma mekanizması Birliği domine eden Almanya ve Fransa'nın yönlendirmelerine açıktır. Kaldı ki, AMB'nin borç krizine karşı aldığı tedbirler, PIIGS ülkelerinin ihtiyaçlarına yönelik olmaktan ziyade o dönemde durgunluğa sürüklenen Almanya ve Fransa ekonomilerini hedef almıştır. İşte bu gibi durumlardan dolayı borç krizine sürüklenen PIIGS ülkelerinin parasal tedbirlerden ziyade mali tedbirlerle desteklenmesi zaruridir.

Parasal Birlik üyelerinin borç krizine karşı alacakları mali tedbirler, hem ülke hem de Birlik düzeyindedir. Borç krizi karşısında ulusal çapta alınacak önlemler "mali konsolidasyon" uygulamaları şeklinde somutluk kazanmıştır. Birlik düzeyinde alınan mali tedbirlerin içeriği ise "kurtarma paketleri" adı altında yeni kredi temin edilmesi, yani re-finansmandır. Mevcut borçların yeniden yapılandırıımasını ve geri ödeme sıkışıkığının hafiflemesini sağlayan re-finansman, kalıcı bir çözüm değildir. Hal böyle olsa da mali durumu sorunlu olan PIIGS ülkelerine uygun koşullarda kredi temin edilebilmesi için AB, önceleri bu ülkelere ayrı ayrı destek sağlama yoluna gitmiştir. Sonrasında ise sağlanan mali destekler tek bir mekanizma çatısı altında toplanmış ve Birlik bünyesinde IMF benzeri bir yapı oluşturulmaya çalışılmıştır. Mali disiplin açısından var olan Maastricht Kriterlerinin tek başına yetersiz kalması ve yaşanan mali krizin daha da derinleşmesi, alınan tedbirlerin çeşitlenmesine neden olmuş ve Parasal Birliğin yanı sıra Mali Birliğin kurulması tartışmaları gündeme gelmiştir. Birlik bünyesinde oluşturulan finansman mekanizmaları ve kurtarma paketleri şu başlıklar altında incelenebilir:

\subsection{Kredi Havuzu: Greek Loan Facility}

Esas itibariyle borç ödemelerinde sorun yaşayan Yunanistan'a kredi sağlamak için tasarlanan ve 10 Mayıs 2010 tarihinde sağlanan bir kredi olanağıdır ${ }^{6}$. Süreklilik özelliğinden yoksun olan bu mekanizmanın toplam tutarı 110 milyar Euro'dur. Bu tutarın 80 milyar Euro'su Avrupa Komisyonu ve 30 milyar Euro'su da IMF tarafından temin edilmiştir. O dönemde Konsey, ülkenin alması gereken mali önlemler karşılı̆ıında Yunanistan'a dilimler halinde toplam 65 milyar Euro kredi kullandırmıştır.

\subsection{Avrupa Finansal İstikrar Mekanizması (AFiM): European Financial Stability Mechanism (EFSM)}

Mali sorun yaşayan tüm üye devletlere finansal destek sağlamak amacıyla kurulmuş bir yapıdır. 2008 krizi sonrasında çok sayıda üye ülkenin bütçe açığı ve borç sorunu yaşaması, borç stokunun ciddi oranlarda artması ve yaşanan mali sorunların Euro için çeşitli riskler oluşturması, bu türden bir mekanizmanın kurulmasında etkili olmuştur. AFiM7', Komisyon'un piyasalardan kredi temin etmesi ve böylelikle $A B$ bütçesi tarafından garanti altına alınan kredilerin sonrasında üye devletlerin kullanımına bırakılması şeklinde işletilmektedir. Toplam büyüklüğü 60 milyar Euro olan ve süreklilik özelliği olmayan AFiM, 2013 yılında yerini Avrupa İstikrar Mekanizmasına bırakmıştır. AFiM imkanlarını kullanmak isteyen devletler Komisyon tarafından uygun bulunan sıkı bir makro ekonomik istikrar programı uygulamak zorundadır. AFiM sayesinde sağlanan kredilerin ilk bölümü 5 Ocak 2011 tarihinde 5 milyar Euro ve ikincisi de 17 Mart 2011 tarihinde 3,4 milyar Euro şeklinde olmak üzere İrlanda'ya aktarılmıştır.

\subsection{Avrupa Finansal İstikrar Fonu (AFiF): European Financial Stability Facility (EFSF)}

9 Mayıs 2010 tarihli Avrupa Birliği Ekonomi ve Maliye Bakanları Konseyi (Economic and Financial Affairs Council: ECOFIN) kararı uyarınca Euro Bölgesi üyesi olan on altı devletin katılımıyla 7 Haziran 2010 tarihinde Lüksemburg kanunlarına tabi bir limitet şirket olarak kurulmuştur. Fonun amacı, üye devletler arasında sadece Euro Bölgesine tabi olanlara geçici mali destek sağlamak ve böylelikle parasal birliğin istikrarını korumaktır. Bu yönüyle ele alındığında AFiF, ölçek açısından AFiM'den farklılaşır. Limited şirket olan AFiF, kredi derecelendirme kuruluşları tarafından en yüksek kredi notu ile derecelendirilmiş ve böylece düşük maliyetli borçlanabilme imkanına kavuşmuştur. Toplamda 440 milyar Euro ile sınırlı olan ve Euro Bölgesine

\footnotetext{
${ }^{6}$ Bilgi için bkz., AB Komisyonu (2020a). Financial Assistance to Greece. https://ec.europa.eu/info/business-economy-euro/economic-andfiscal-policy-coordination/eu-financial-assistance/which-eu-countries-have-received-assistance/financial-assistance-greece en\#firstprogramme-for-greece

${ }_{7}$ Bilgi için bkz., AB Komisyonu (2020b) European Financial Stabilisation Mechanism (EFSM). https://ec.europa.eu/info/ business-economyeuro/economic-and-fiscal-policy-coordination/eu-financial-assistance/loan-programmes/european-financial-stabilisation-mechanismefsm en
} 
üye devletler tarafından garanti altına alınan AFiF imkanlarından ilk yararlanan ülke 17,7 milyar Euro ile i̇rlanda olmuştur. 17 Mayıs 2011 tarihinde Portekiz'e de 26 milyar Euro kaynak sağlanması kararlaştırılmıştır. AFif ${ }^{8}$ de yerini 2013 yılında Avrupa İstikrar Mekanizmasına bırakmıştır.

\subsection{Avrupa İstikrar Mekanizması (AIM): European Stability Mechanism (ESM)}

Euro Bölgesi'nde mali sıkıntıları olan üye devletlere, izledikleri mali tedbirleri desteklemek amacıyla 500 milyar Euroluk kredi verme kapasitesi ile 27 Eylül 2012 tarihinde kurulmuş daimi bir çözüm mekanizmasıdır. Parasal Birliğe üye olan tüm devletler statüleri gereği AiM üyesidir. AiM, önceki dönemlerde kurulan iki geçici fonlama programının yerini almış ve mali sıkıntılara düşmesi durumunda üye devletlere kurtarma paketleri sunma görevi üstlenmiştir. Merkezi Lüksemburg'da olan AiM ${ }^{9}$, finansman faaliyetlerini para piyasası araçlarının yanı sıra otuz yıla kadar orta ve uzun vadeli borçlanma araçları ihraç ederek yerine getirmektedir.

\subsection{Euro Rekabet Paktı: Euro Plus Pact (EPP)}

$A B$, borç krizi yaşayan PIIGS ülkelerinin finansman sorunlarına yönelik tedbirlerin ardından küresel ekonomide rekabetçi bir birlik haline gelmek için somut adımlar atmış ve 2020 Stratejisini ortaya koymuştur. Birliğin 2000'li yıllarda sergilenen düşük büyüme performansı bu süreçte etkili olmuştur.

\section{Grafik 2: Çin, Hindistan, ABD ve Euro Bölgesi'nin Büyüme Oranları, 1998-2018}

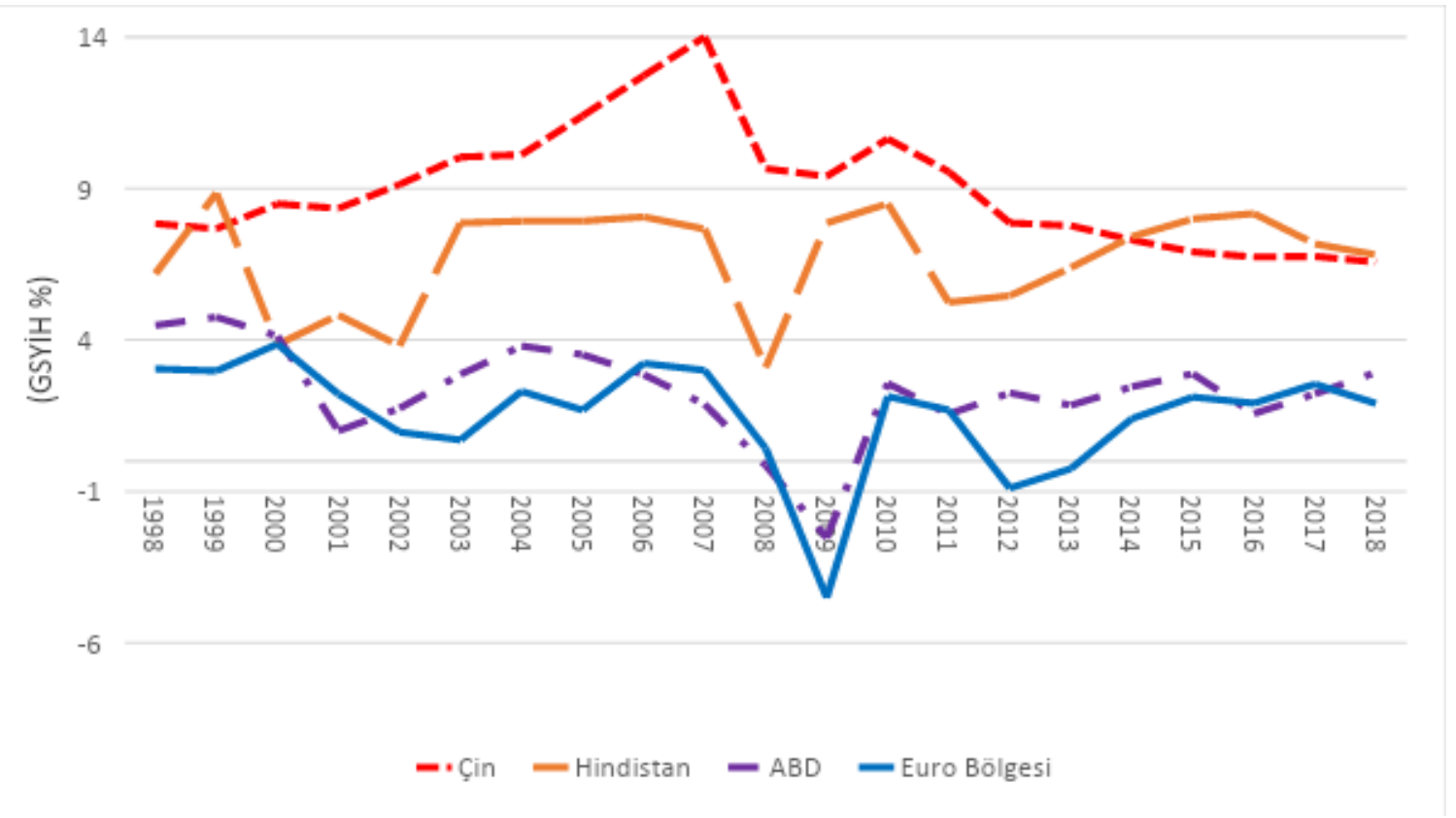

Kaynak: www. worldbank.com Dünya Bankası verileri kullanılarak tarafımızca düzenlenmiştir (13 Mart 2020).

Grafik 2'de görüldüğü üzere Euro Bölgesi ekonomilerinin büyüme performansları -ortalama değer olarak- genelde ABD ile uyumlu iken özellikle Çin ve Hindistan'ın oldukça gerisindedir. Ayrıca 2011 yılında yaşanan borç krizinin sadece Euro Bölgesi için ikinci bir kriz dalgası oluşturması, yani W tipi çift dipli krize sebep olması AB'nin büyüme performansının düşük seviyede kalmasının en önemli sebebidir. Küresel rekabette üç dev ekonominin gerisinde kaldığı yıllarda $A B$, borç krizinin aşılmasına yönelik olarak mali açıdan zor durumdaki PIIGS ülkelerine yönelik kredi mekanizmaları oluşturmuş ve bu ülkelerin mali durumlarını güçlendirmeye yönelik somut adımlar atmıştır. Birliği domine eden Almanya ve Fransa, 4 Şubat 2011 tarihli $A B$ Konsey toplantısında küresel rekabet gücünün arttırılması için üye devletlerin rekabet güçlerinin artırılmasını hedefleyen bir pakt kurulmasını önermiştir (Öztürk ve Aras, 2011: 157). Bu öneri kapsamında şu türden önlemlerin alınması talep edilmiştir

\footnotetext{
${ }^{8}$ Bilgi için bkz., ESM (30 Şubat 2020a). Before the ESM. https://www.esm.europa.eu/efsf-overview.

${ }^{9}$ Bilgi için bkz., ESM (30 Şubat 2020b). About Us. https://www.esm.europa.eu/about-us
} 
(AB Bakanlığı, 2011):

- Birlik bünyesinde fiyat artışına endekslenen ücret ve maaş uygulamasından vazgeçilmesi. Ücret ve maaş artışlarının işgücü verimliliğine göre belirlenmesi

- İşgücünün Birlik içindeki mobilitesinin artırılabilmesi için diploma ve mesleki yeterliliklerin karşılıklı tanınarak uyumlaştırılması

- Üye devletlerdeki emeklilik sistemlerinin demografik gelişmelere göre yeniden düzenlenmesi ve ulusal emeklilik sistemlerinin birbirleri ile uyumlu hale getirilmesi

- Üye devletlerde borç erken uyarı sistemleri oluşturulmasına yönelik anayasal düzenlemeler yapılması

- Üye devletlerdeki Kurumlar Vergisi mevzuatlarının uyumlu hale getirilmesi

- Banka ve finans kurumları için kriz yönetimi sistemlerinin kurulması

PIIGS ülkeleri Almanya ve Fransa'nın bu önerilerine karşı çıkmıştır. Bunda vergi ve emeklilik sistemleri ile demografik yapı konularında ülkelerin farklı tercihlerinin olması ve özellikle maliye politikasının kullanılabilir tek politika aracı olarak elde kalması isteği etkili olmuştur. Ayrıca bu öneriler kapsamında üye devletlerin izlediği politikaların birbirine yakınsayamayacağı, domine konumdaki Almanya ve Fransa ile var olan farkın daha da açılacağı ve PIIGS ülkelerinin getirilen kurallara uzun vadede uyum sağlamada sorun yaşayacakları ileri sürülmüştür (Gogas, 13 Şubat 2011).

PIIGS ülkelerinden gelen itirazlar üzerine Almanya ve Fransa'nın önerileri esnetilmiş ve 2011 yılı Mart ayında Euro Rekabet Paktı (Euro Plus Pact) kurulmuştur. Kurulan pakt kapsamında Euro Bölgesi üyelerinin rekabet güçlerinin artırılması için şu önlemlerin alınması kararlaştırılmıştır (AB Bakanlığı, 2011):

- Ücret artışlarının işgücü verimlilik artışları ile uyumlu hale getirilmesi

- Işgücü maliyetlerinin AB ve Dünya ile karşılaştırılmalı olarak izlenmesi

- Verimlilik sorunu yaşayan ülkelere yönelik özel önlemler alınması

- Bürokratik engellerin azaltılması ve işgücü piyasasına esneklik kazandırılması

- $\quad$ Eğitim sistemlerinin reforme edilmesi

Euro Rekabet Paktı kapsamında ayrıca (i) kamu maliyesinde sürdürülebilirliğin sağlanabilmesi ve (ii) mali istikrarın güçlendirilmesi amacıyla şu önlemlere yer verilmiştir (AB Bakanlığı 2011):

- Üye ülkelerde "borç freni", "birincil fazla" veya "harcama kuralı" gibi mekanizmalar oluşturulması ve İstikrar ve Büyüme Paktı (IBP)'deki mali kuralların ulusal mevzuatlarına eklenmesi

- Emeklilik sistemi reformu yapılması ve emekli olma yaşının yükseltilmesi

- $\quad$ Finans piyasaları ile bankaların etkin şekilde denetlenmesi

- Vergi politikalarının koordinasyonun sağlanması

AB'nin küresel ölçekte rekabet edebilirliğini arttırmayı amaçlayan Euro Rekabet Paktı, görüldüğg̈ü üzere üye ülkelerin özellikle ekonomik performanslarını geliştirmeyi amaçlamış ve bu kapsamda ücretlerin küresel rekabet ortamına uyumlu hale getirilmesi, işgücü yetkinliklerinin artırılması, emeklilik sistemlerinin reforme edilmesi gibi sosyal içerikli tedbirlerin yanı sıra finansal sistem ve özellikle de kamu maliyesi sorunlarının aşılarak bunların güçlendirilmesini amaçlamış tedbirlerden oluşmuştur. Söz konusu tedbirler Birliğin zayıf halkaları olan PIIGS ülkelerinin mali ve ekonomik açıdan güçlenmeleri için $A B$ özelde Almanya ve Fransa tarafından bir anlamda dayatılan yapısal reform tavsiyeleridir.

\subsection{Altılı Paket}

Birlik tarafından alınan iBP'yi güçlendirmeyi amaçlayan tedbirler bütünüdür. Söz konusu tedbirler 13 Aralık 2011 tarihinde yürürlüğe giren altı yasal düzenlemeden oluştuğu için Altılı Paket olarak adlandırılmıştı. Altılı Paket kapsamında AB'nin ekonomik yönetişimi güçlendirilmek istenmiş ve ulusal bütçe ve ekonomi politikalarının Avrupa Sömestri adı altında Birlik tarafından izlenmesi amaçlanmıştır. En son Eylül 2012 tarihinde güncellenen Altılı Paket ile iBP üzerinde şu tür değişiklikler yapılmıştır (AB Bakanlığı 2011 ve AB Komisyonu, 2020c):

- Makroekonomik dengesizliklerin önlenmesi ve düzeltilmesine ilişkin Makroekonomik Dengesizlik Prosedürü 
$(M D P)^{10}$ ile Aşırı Dengesizlik Prosedürü (ADP) oluşturulmuştur. Böylece ekonomik verilerinde ciddi dengesizlikler tespit edilen üyeler için ADP izlenecektir. ADP kapsamına alınan üye devlet, belli bir takvime bağlı olarak alacağı önlemleri içeren düzeltici bir eylem planı hazırlayacaktır. ADP tavsiyelerini uygulamakta sürekli başarısız olunması durumunda ise söz konusu ülkeye kendi GSYH'sının Binde 1'i tutarında yıllık para cezası kesilecektir.

- Üye devletlerdeki kamu harcamalarına kural konularak harcamalardaki genişlemenin potansiyel büyüme oranını aşmaması sağlanacaktır.

- Borç Stoku/GSYH oranı yüzde 60'ı aşan ülkeler, borç stoklarını üç yıl boyunca ve her yıl GSYH'lerinin yüzde 60'ını aşan kısmın 1/20'si kadar azaltacaktır.

- IBP amaçları ulusal bütçe çerçevelerine yansıtılacak ve kamu maliyesine ilişkin çok yıllı planlama yaklaşımı benimsenecektir.

- En fazla GSYH'nin yüzde 3'ü kadar olabilen bütçe açığı kuralının üzerinde aşırı bütçe açıkları görülen veya borç stoklarını yeterli hızda azaltamayan üye devletler hakkında Aşırı Eksiklik Prosedürü (AEP) izlenecektir.

- Üye devlet performanslarında ciddi sapma oluşması halinde ülke GSYH'nin binde 2'si oranında faizli teminat, aşırı açık verilmesi durumunda ise aynı oranda faizsiz teminat uygulaması söz konusu olacaktır. AB tavsiyelerini dikkate almayan ülkelerin söz konusu teminatları cezaya çevrilebilecektir.

Üye ülkelerin özellikle kamu maliyesi performanslarını arttırmayı amaçlayan Altılı Paket, var olan AAP tedbirlerini bir yenilik olarak getirdiği ADP tedbirleri ile daha da genişletmiş ve üye ülkelerin alacakları ekonomik tedbirleri tek tipleştirmiştir. Altılı Paket, var olan Maastricht Kriterleri'ne uyumun gerekliliğini somut şekilde ortaya koymuş ve böylelikle mali kurallara bağlı kalınmasının önemini vurgulamıştır.

\subsection{Avrupa Mali Birliği}

Ekonomik ve Parasal Birlikte Kararlılık, Koordinasyon ve Yönetişim Antlaşması 1 Şubat 2012 tarihinde Çek Cumhuriyeti, Hırvatistan ve o dönemde Birlik üyesi konumunda olan Britanya haricinde kabul edilmiş ve bu anlaşma ile ulusal bütçelerin dengelenmesi amaçlanmıştır. 2013 yılı itibariyle yürürlüğe giren ve taraf ülkeleri bağlayan bu anlaşma ile şu önlemler alınmıştır (AB Komisyonu, 2020d):

- Genel bütçe dengede olmalı veya fazla vermelidir. Yıllık yapısal açık, GSYH'nin binde 5'ini geçmemelidir. Borç yükü oranı yüzde $60^{\prime} ı$ altında olan ve kamu maliyesinin uzun dönemde sürdürülebilirliği açısından risk taşımayan ülkelerin yapısal açığı en fazla GSYH'nin binde 1'i kadar olabilir.

- Borç yükü yüzde 60 referans seviyesini geçen ülkeler, yüzde 60'ı aşan kısmın yıllık ortalama en az 1/20'si kadar üç yıllık dönemde bir azalma sağlamalıdır.

- Mali gerçekleşmeler ilk iki kurala uyumlu değilse ve orta vadeli hedeflerden önemli sapma gözlemleniyorsa otomatik düzeltme mekanizması devreye girmelidir.

- Söz konusu üç kural, antlaşmanın ilgili ülkede yürürlüğe girmesini takiben en geç 12 ay içerisinde ulusal mevzuata anayasal veya eşdeğer bir düzeyde kalıcı olarak aktarılmalıdır.

- Antlaşma hükümlerine uyulup uyulmadığı konusunda yetki iBP'de olduğu gibi Konseye verilmemiş Avrupa Birliği Adalet Divanına ( $A B A D$ ) verilmiştir. ABAD'ın uyarılarına rağmen söz konusu uyumsuzluklar giderilmediği takdirde ABAD muhatap ülkeye GSYH'nin binde 1'ine kadar para cezası verebilecektir. Söz konusu para cezası Parasal Birlik üyesi bir ülkeye kesildiyse AiM'e, Para Birliği dışında bir ülkeye kesildiyse AB bütçesine aktarılacaktır.

- Hakkında AAP açılan üyeler, aşırı açıkların etkili olarak düzeltilmesine yönelik yapısal reformların detaylandırıldığı ekonomik ortaklık programlarını Komisyon ve Konsey'e sunacaklardır. Programın ve yıllık bütçe planlarının uygulanması Komisyon ve Konsey tarafından takip edilecektir.

- Antlaşmaya taraf ülkeler, daha iyi koordinasyon ve planlama sağlanması amacıyla, sermaye piyasalarından yapacakları borçlanma planlarına ilişkin olarak Konsey ve Komisyon'a önceden rapor sunacaktır

Görüldüğüü üzere $A B^{\prime}$ nin yöneldiği mali birlik uygulaması, parasal birlikte olduğu gibi para politikasının tek merkezden yönetimi gibi somut bir gelişme değildir. Bu aşamada mali birliğin, mali politikanın tek merkezden yönetimi olarak değil, ulusal mali

102011 yılında başlatılan MDP ile belirli bir üye ülke veya bir bütün olarak birlik bünyesinde ekonomik istikrarı olumsuz etkileyebilecek potansiyel olarak zararlı makroekonomik dengesizliklerin tanımlanması ve önlenmesi amaçlanmıştır. Bilgi için bkz., AB Komisyonu (2020c). History of The Stability and Growth Pact. https://ec.europa.eu/info/business-economy-euro/economic-and-fiscal-policy-coordination/eueconomic-governance-monitoring-prevention-correction/stability-and-growth-pact/history-stability-and-growth-pact_en\#1997) 
politikaların koordinasyonu olarak anlaşılması gerekir. Günümüzde $A B^{\prime}$ de mali birlik vurgusu, üye devletlerin parasal birliğin daha iyi işlemesi için alacakları tedbirlerin ve uygulayacakları ekonomik reformların $A B$ kurumları ile koordineli şekilde yürütülmesi için verdikleri birer söz niteliğindedir.

\section{PIIGS ÜLKELERINE AIT KAMU MALIYESI PERFORMANSLARI}

$A B$ ve özellikle Parasal birlikte, üye ülkelerin kamu maliyesi performansları, 1993'te yürürlüğe giren Maastricht Antlaşması sayesinde birer mali kural haline getirilmiştir ${ }^{11}$. Buna göre, parasal birlik ve bu birliğe aday olan ülkelerde bütçe açıklarının ülke GSYH'sine oranı en fazla yüzde 3 olmalıdır. Ayrıca [Borç Stoku/GSYH] ile formüle edilen borç yükleri de yüzde 60 sınırını aşmamalıdır. Dikkat edilecek olursa oluşturulan bu kurallar, doğrudan doğruya ülkelerin kamu maliyesi performanslarını güçlendirmeye yöneliktir. Çünkü güçlü bir kamu maliyesi, Parasal Birliğin sağlam temeller üzerine yükselmesinin ön şartıdır. Bu yönüyle ele alındığında, çalışma alanımızı oluşturan PIIGS ülkelerine ait kamu maliyesi performanslarının Maastricht Kriterleri kapsamında uzun dönemli bir perspektifte ortaya konulması, yapılması gereken tespitlerin başında gelir.

\subsection{PIIGS Ülkelerindeki Bütçe Açıkları}

Mali açıdan kırılganlıkları yüksek olan PIIGS ülkelerinin bütçe açıkları bakımından sergiledikleri performanslar genel hatları ile benzerlik göstermektedir. Buna göre, yapısal bir kırılma olarak ele alındığında 2008 Krizi, bazı PIIGS ülkelerinde bütçe açığı sorunu yaratmış, bazılarında ise var olan bütçe açığı sorununu derinleştirmiştir. Ülkelerin ulusal ölçekte izlediği mali konsolidasyon tedbirleri ile Birlik düzeyinde alınan tedbirler sayesinde yaşanan bütçe açı̆̆ı sorunu hafifletilmiş ve mali disiplin arzulanan seviyeye yükselmiştir. Grafik 3'de PIIGS ülkelerinin bütçe açıkları bakımından sergiledikleri son yirmi yıllık performanslar gösterilmiştir.

\section{Grafik 3: PIIGS Ülkelerindeki Bütçe Açığı/GSYH Oranları: 1998-2018}

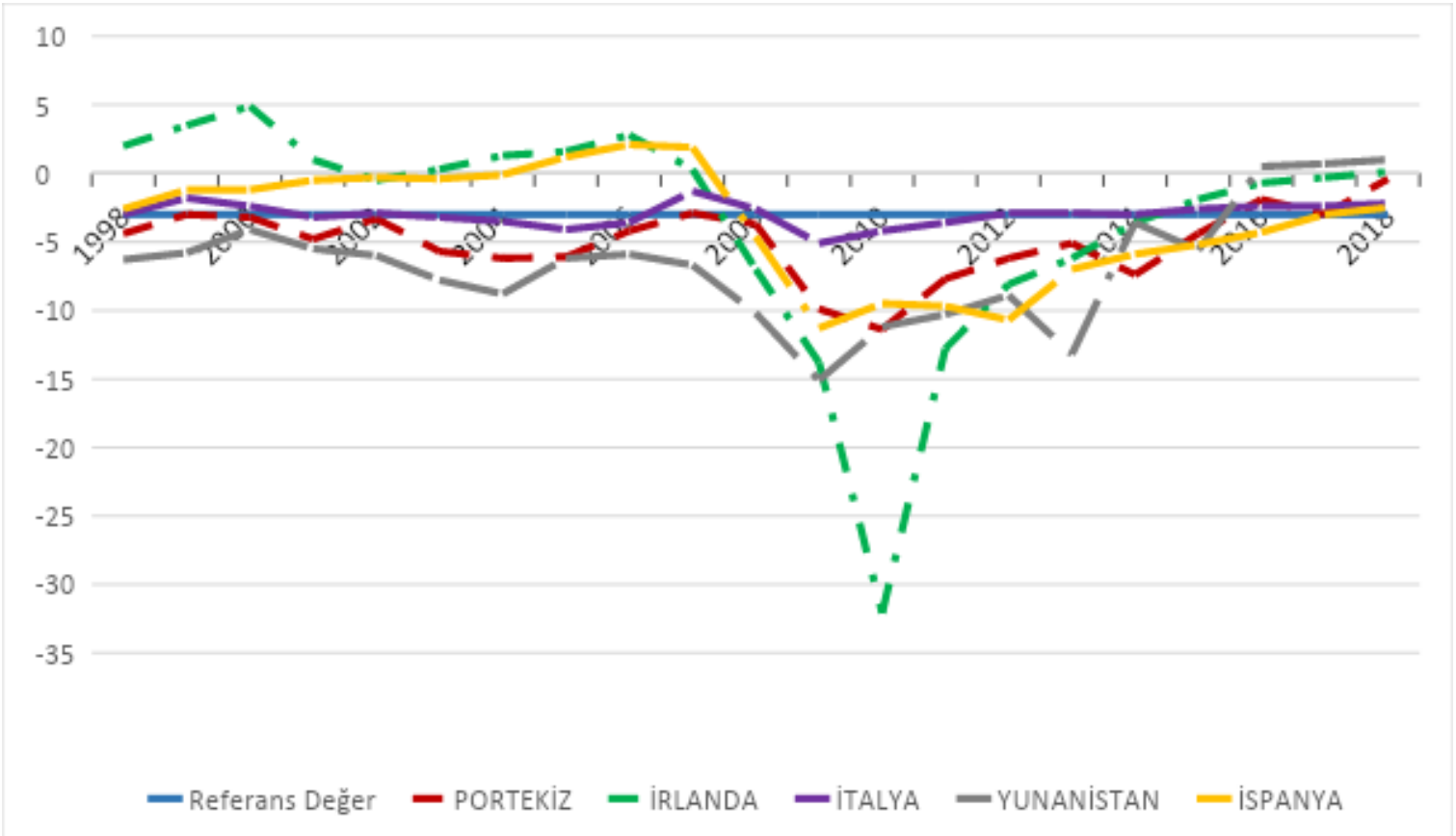

Kaynak: https://ec.europa.eu/eurostat/data/database EUROSTAT verileri kullanılarak düzenlenmiştir. (29 Ocak 2020)

PIIGS ülkelerinin “Bütçe Açığı/GSYH Oranı” kriterine uyumları hakkındaki tespitlerimiz şöyledir¹2:

A- (i) Portekiz'in 2002 yılına kadar verdiği bütçe açıkları, referans değere oldukça yakındır. Lakin ülkedeki bütçe açıkları, 2002-

\footnotetext{
${ }^{11}$ Bütçe açıkları hakkında duyulan hassasiyet, Keynesyen yaklaşımın gözden düşmesiyle 1980 'lerde geri gelir ve o dönemde monetarist yaklaşımın para arzı ve enflasyon arasında oluşturduğu güçlü nedensellik ilişkisi, Fiyat Düzeyinin Maliye Teorisi katkıları ile desteklenir. Buna göre, fiyat istikrarını sağlama bakımından sadece para arzının kontrolü yeterli değildir. Ülkelerin sergilediği kamu maliyesi performansları da belirleyicidir. Bu bakımdan bütçe açıkları kontrol altına alınmalı ve bu açıkların sebep olduğu borç yükü düşürülmeli, borç stoku sürdürülebilir hale getirilmelidir. Ayrıntılı bilgi için bkz., Uygur, 2001: 7-23.

${ }^{12}$ Değerlendirmeleri öze indirgemek için trendlerde oluşan kırımalara verilen (A), (B) ve (C) vurguları tarafımıza aittir. Yapılan değerlendirmelerde PIIGS kısaltmasındaki ülke sıralaması kullanılmışır.
} 
2006 arası dönemde artmış ve referans değerin iki katı bir düzeye ulaşmıştır. AB Konseyi, bu dönemde ülke için 20 Eylül 2005 tarihinde 2005/730/EC sayılı kararla ${ }^{13}$ Aşırı Açık Prosedürü (AAP) açmıştır. AB Komisyonu prosedürün sona erdirilmesi için Konseyin 12401/05 sayılı kararıyla benimsediği önerisiyle ${ }^{14}$ ülkenin 2008 yılına kadar bütçe açığını referans değeri sağlar hale getirmesini, bunun için de açığın 2006 yılında yüzde 1,5 ve sonraki iki yılda da en az yüzde 0,75 oranında iyileştirilmesini önermiştir. Alınan bu tedbir sonrasında Portekiz, bütçe açıklarını disiplin altına almış ve bütçe açıklarını Küresel Krizin ortaya çıktığı 2008 yılına kadar referans değere yakınlaştırmıştır. (ii) İrlanda 1999-2001 yılları arasında yüzde 3,5 ile 4,9 arası değer alan bütçe fazlaları vermişken ortak para birimi Euro'ya geçtiği 2002 yılında yüzde 0,5 oranında bütçe açığı vermiştir. Bu yılın haricinde İrlanda'daki bütçe performansı üst düzeyde gerçekleşmiş ve ülke bütçesi, 2008 Krizine kadar olan dönemde fazla verilerek kapatılmıştır. (iii) İtalya'daki bütçe açıkları, uzun yıllar referans değere yakın bir seyir izlemiştir. Euro'ya geçtiği 2002 yılında referans değerin üstünde bir performans gösteren bütçe açı̆̆ı, yavaş yavaş referans değerin üzerine çıkmış ve ülke için 2005 yılında AB Konseyi'nin 2005/694/EC ${ }^{15}$ kararıyla AAP açılmıştır. AB Komisyonu Konseyin 11912/05 sayılı kararıyla kabul ettiği önerisinde ${ }^{16}$ ülkenin aşıı açığı 2007 yılına kadar azaltmasını tavsiye etmiştir. (iv) Veri skandalına sebep olan ve sonradan verileri güncellenen Yunanistan'ın şartları sağlamadığı halde Parasal Birliğe girdiği anlaşılmıştır. Ülkenin bütçe açıkları 2008 Krizi öncesi dönemde yüzde 5 düzeyinde seyretmiştir. Konsey, Yunanistan için de 2004 yılında 2004/917/EC sayılı kararıyla ${ }^{17}$ AAP açmıştır. (v) Küresel kriz öncesinde İspanya, referans değerin altında ve giderek azalan oranda bütçe açığı vermiş ve hatta söz konusu açık, 2005 yıında bütçe fazlasına dönüşmüştür. Mali disiplin hakkında ciddi gelişmeler sağlanan bu dönem, diğer PIIGS ülkelerinde olduğu gibi 2008 kriziyle sona ermiştir.

B- (i) Parasal Birliğe girişi sonrasında referans değere uyum sağlamada zorlanan Portekiz, 2008 Kriziyle birlikte ciddi bütçe açıkları vermeye başlamıştır. Kriz öncesi dönemde referans değere ulaşma bakımından bütçede disiplin sağlayan ülke, kriz sonrası dönemde yüzde 7'nin altına düşmeyen -yüksek- oranlarda bütçe açıkları vermiş ve ülkedeki bütçe açı̆ı, 2010 yılında yüzde 11,4 ile zirveye ulaşmıştır. Konsey 2010 yılında ülke için 2010/288/EU sayılı kararıyla ${ }^{18}$ AAP açmıştır. (ii) Referans değeri rahatılıkla sağlayan İrlanda'nın bütçe performansı, 2008 Kriziyle birlikte alt üst olmuştur. Öyle ki, ülke 2010 yılında verdiği yüzde 32'lik devasa açıkla PIGS ülkeleri arasına girmiş ve kısaltmanın PIIGS'e dönüşmesine sebep olmuştur. Ülke, referans değeri beş yıllık bir kesinti sonrasında ancak 2015 yılında sağlayabilmiştir. (iii) Kriz öncesinde referans değer dolaylarında bütçe açığı veren İtalya da -diğer PIIGS ülkeleri gibi ağır olmasa da- krizden etkilenmiştir. Lakin ülkenin bütçe açıklarının tutarı yüksek seviyeli olduğundan -ki 2009 yılında 80 milyar Euro'dur- ülke için 2010 yılında Konseyin 2010/286/EU sayılı kararıyla19 AAP açılmıştır. (iv) Önceki dönemlerde zaten yüzde 3'ün üzerinde seyreden bütçe açıkları, Yunanistan'da 2008 Krizi sonrasında çift haneli sayılara ulaşmış ve ülkedeki bütçe açığı 2013 yılında yüzde 13,2 olarak gerçekleşmiştir. (v) 2008 Krizi ile bütçe disiplinini kaybeden İspanya, kriz döneminde diğer PIIGS ülkelerinde olduğu gibi hızla referans değerden uzaklaşmış ve ülkenin bütçe açıkları çift haneli sayılara çıkmıştır. Konsey, İspanya için 2009 yılında 2009/417/EC sayılı kararla ${ }^{20}$ AAP açılmasına karar vermiştir.

C- (i) Kriz sonrası dönemde Portekiz, izlediği mali konsolidasyon tedbirleri sayesinde bütçe açıklarını yüzde 6 seviyesine çekmiş ve 2014 yılında yaşanan kısa süreli gerileme sonrasında ülke, referans değeri sağlar konuma gelmiştir. (ii) İrlanda'da izlenen sıkı mali konsolidasyon tedbirleri sayesinde 2015 yılı itibariyle kontrol altına alınan bütçe açığı, 2018 yılında bütçe fazlasına dönüşmüştür. (iii) 2008 Krizi sebebiyle bütçe performansı kısa süreli olarak kötüleşen İtalya'nın bütçe açıkları yeniden yüzde 3'lük referans değer dolaylarına çekilmiştir. (iv) En sorunlu PIIGS ülkesi olan Yunanistan, aldığı sert mali konsolidasyon tedbirleri sayesinde bütçe açığını hızla azaltmış ve 2016 yılı sonrasında bu açıkları bütçe fazlasına dönüştürmüştür. (v) Kriz sonrası dönemde görece geç toparlanan İspanya' da bütçe açığı, her ne kadar yüzde 5'in altına düşmemiş olsa da 2018 yılında

\footnotetext{
${ }^{13}$ Bilgi için bkz., AB Konseyi (20 Eylül 2005a) Council Decision of 20 September 2005 on the Existence of an Excessive Deficit in Portugal (2005/730/EC). https://eur-lex.europa.eu/legal-content/EN/TXT/?uri=uriserv:OJ.L_.2005.274.01.0091.01.ENG, (11.03.2020)

${ }^{14}$ Bilgi için bkz., AB Konseyi (7 Ekim 2005) Council Recommendation with a View to Bringing an End to the Situation of an Excessive Government Deficit in Portugal (12401/05). http://data.consilium.europa.eu/doc/document/ST-12401-2005-INIT/en/pdf, (11.03.2020)

${ }^{15}$ Bilgi için bkz., AB Konseyi (28 Temmuz 2005) Council Decision of 28 July 2005 on the Existence of an Excessive Deficit in Italy (2005/694/EC). https://ec.europa.eu/economy finance/economic governance/sgp/pdf/30 edps/104-06 council/2005-07-28 it 104-6 council_en.pdf, $(10.03 .2020)$

${ }^{16}$ Bilgi için bkz., AB Konseyi (20 Eylül 2005b) Council Recommendation with a View to Bringing an End to the Situation of an Excessive Government Deficit in Italy (11912/05). https://ec.europa.eu/economy finance/economic governance/sgp/pdf/30 edps/10407 council/2005-07-28 it 104-7 council en.pdf, (11.03.2020)

${ }^{17}$ Bilgi için bkz., AB Konseyi (5 Temmuz 2004) Council Decision of 5 July 2004 on the Existence of an Excessive Deficit in Greece (2004/917/EC). https://eur-lex.europa.eu/legal-content/EN/TXT/?uri=uriserv:OJ.L .2004.389.01.0025.01.ENG, (11.03.2020)

${ }^{18}$ Bilgi için bkz., AB Konseyi (19 Ocak 2010a) Council Decision of 19 January 2010 on the Existence of an Excessive Deficit in Portugal (2010/288/EU). https://eur-lex.europa.eu/legal-content/EN/TXT/?uri=uriserv:OJ.L .2010.125.01.0044.01.ENG, (11.03.2020)

${ }^{19}$ Bilgi için bkz., AB Konseyi (19 Ocak 2010b) Council Decision of 19 January 2010 on the Existence of an Excessive Deficit in Italy (2010/286/EU). https://ec.europa.eu/economy finance/economic governance/sgp/pdf/30 edps/104-06 council/2009-12-02 it 1266 council en.pdf, $(10.03 .2020)$

${ }^{20}$ Bilgi için bkz., AB Konseyi (27 Nisan 2009) Council Decision of 27 April 2009 on the Existence of an Excessive Deficit in Spain (2009/417/EC) https://eur-lex.europa.eu/legal-content/EN/TXT/?uri=uriserv:OJ.L.2009.135.01.0025.01.ENG, (10.03.2020)
} 
yüzde 2,5 olarak gerçekleşmiştir. Böylelikle izlenen mali konsolidasyon tedbirleri sayesinde PIIGS ülkelerinin tümündeki bütçe açıkları, yüzde 3 kuralını sağlar hale gelmiş ve AAP uygulamasına alınan herhangi bir PIIGS ülkesi kalmamıştır.

PIIGS ülkeleri 2008 krizinin etkisiyle bütçe açıklarını kontrol etmede ciddi sorunlar yaşamışsa da izledikleri mali konsolidasyon tedbirlerinin de etkisiyle yaklaşık on yıl içinde bütçe performanslarını iyileştirmeyi başarmışlardır. Geçmiş dönemde mali kırılganlıkları yönünden etkili olan bütçe açıkları, sağlanan mali disiplinin etkisiyle artık sorun olmaktan çıkmıştır. Ayrıca bütçe açıkları için 1993 yılında getirilmiş olan "en fazla yüzde 3 açık" kuralına belli bir zaman boşluğu sonrasında olsa da PIIGS ülkeleri 2018 yılı itibariyle uyum sağlamıştır. Bütçe açıkları, ele aldığımız dönemin sonunda bu ülkeler için sorun olmaktan çıkmıştır.

\subsection{PIIGS Ülkelerindeki Borç Yükleri}

2008 Krizi, PIIGS ülkelerindeki borç yüklerinin gelişimi açısından da belirleyici olmuştur. Buna göre oluşan genel görünüm, kriz sonrasında ülke borç yüklerinin çarpıcı şekilde yükselmesidir. 2010 yılında en sorunlu PIIGS ülkesi olan Yunanistan'ın sürüklendiği borç krizi, durumu benzerlik gösteren ülkeler üzerinden okunduğunda "Avrupa Borç Krizi" olarak adlandırılmış ve özellikle Avrupa Parasal Birliği'nin geleceğinin sorgulanmasına sebep olmuştur. Grafik 4'de görüleceği üzere PIIGS ülkelerinin borç yükleri bakımından son yirmi yıllık performansları şöyledir:

\section{Grafik 4: PIIGS Ülkelerindeki Borç Yüklerinin Gelişimi: 1998-2018}

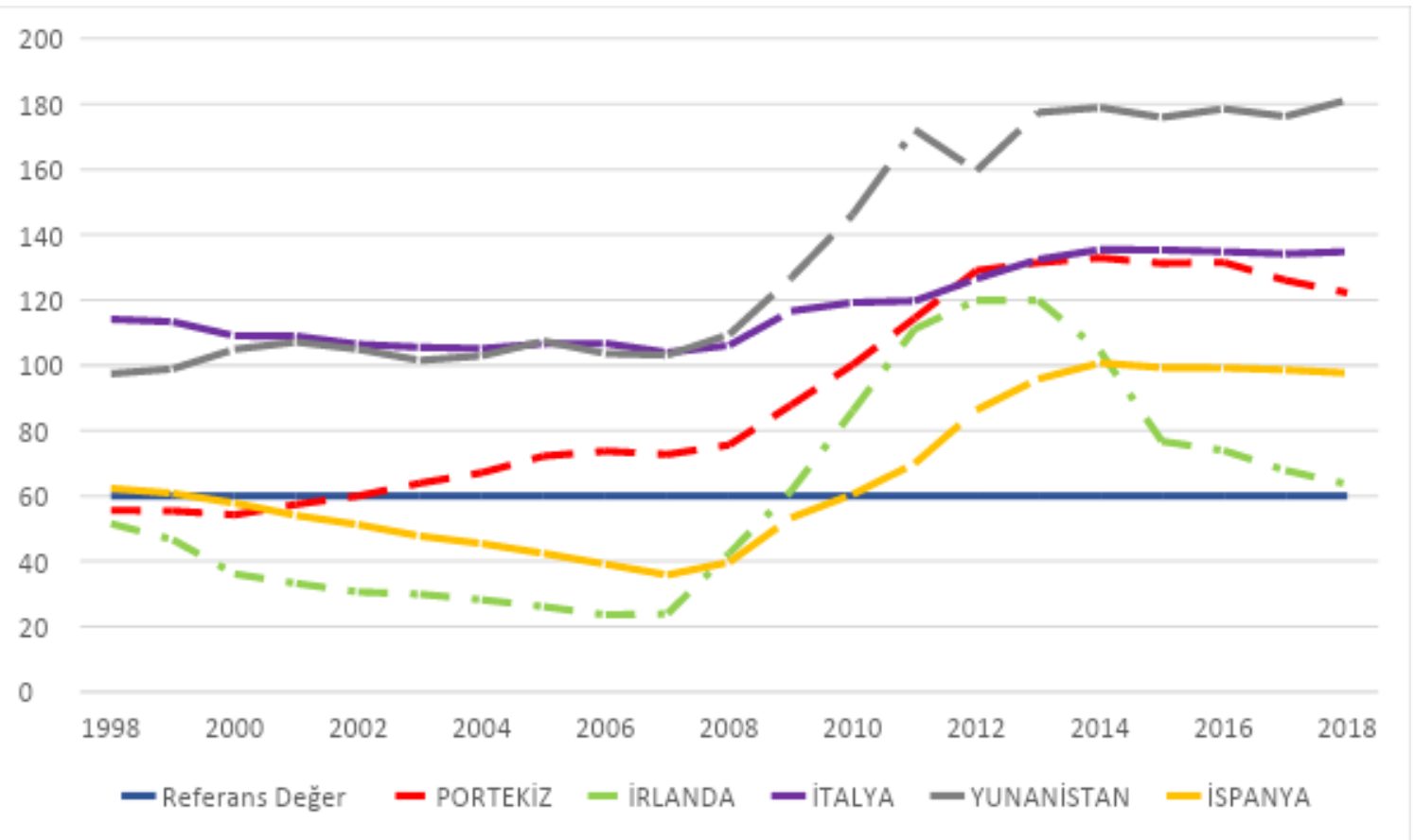

Kaynak: https://ec.europa.eu/eurostat/data/database EUROSTAT verileri kullanılarak düzenlenmiştir (29 Ocak 2020).

PIIGS ülkelerinin "Borç Stoku/GSYH Oranı" kriterine uyumları hakkındaki tespitlerimiz sırasıyla şöyledir:

A- (i) Portekiz'deki borç yükünün referans değer olan yüzde 60'ı sağlaması bakımından Euro kullanımına geçtiği 2002 yılı, bir tür kırılma yılıdır. Ülkenin borç yükü bu yılın öncesinde referans değeri sağlamış görünse de sonraki dönemlerde referans değerden uzaklaşmış ve 2008 Krizi öncesinde yüzde 70-80 bandına çıkmıştır. Borç yükündeki bu seyir ülkenin mali açıdan kırılgan olması şeklinde yorumlanmıştır. (ii) Referans değeri sağlayan ve borç yükü yönetimi bakımından başarılı olan ỉrlanda, bu dönem boyunca sahip olduğu bütçe disiplininin de etkisiyle borç yükünü istikrarlı bir şekilde azaltmış ve kriz öncesinde yüzde 23 seviyesine çekmiştir. (iii) Milli geliri bakımından AB'nin en büyük üçüncü ekonomisi olan İtalya, borç yükü için belirlenen referans değeri sağlamadığı halde Parasal Birliğe alınmış ve yüzde 60 olması gereken borç yükü, dönem boyunca iki katına yakın olan yüzde 100-120 bandında seyretmiştir. Bütçe açıkları bakımından pek de kırılgan olmayan ekonomi, borç yükü bakımından oldukça sorun yaşamış ${ }^{21}$ ve ülke, borç yükünün düşürülmesi yönünde herhangi bir kazanım sağlayamamıştır.

${ }^{21}$ EUROSTAD ülke istatistikleri incelendiğinde İtalya'nın yaşadığı borç yükü sorunu, diğer PIIGS ülkeleri ile karşılaştırıldı̆ı̆nda bariz şekilde ortadadır. 1998 yılında İtalya'daki borç stoku yaklaşık 1,300 trilyon Euro iken diğer PIIGS ülkelerinde toplam 576 milyar Euro'dur. 2008 ylında bu tutarlar sırasıyla 1,738 trilyon Euro ile 620 milyar Euro ve 2018 yılında da yine sırasıyla 2,380 trilyon Euro ile 1,963 trilyon Euro'dur. 
(iv) Borç yükünde ciddi sorunlar yaşayan Yunanistan da -italya gibi- borç yükü kriterine uyum sağlayamadığı halde Parasal Birlik üyesi olmuş ve ülkedeki borç yükü -miktar olarak İtalya'dan çok düşük olsa da benzer şekilde- yüzde 100-120 bandına yerleşmiştir. (v) İspanya'da borç yükü, Parasal Birlik üyesi olmasıyla birlikte düzenli ve hatta artarak azalmıştır. Ülkenin izlediği mali konsolidasyon uygulamaları etkili olmuş ve borç yükündeki azalma, azalan bütçe açıklarıyla birlikte gerçekleşmiştir. 0 dönemde İspanya'daki borç yükü yüzde 35 düzeyine kadar gerilemiştir.

B- 2008 yılında yaşanan krizin kısa sürede yayılmasıyla birlikte -görece farklılıklar olsa da PIIGS ülkelerinin hepsinde ülke borç yükleri artma eğilimine girmiştir. (i) Kriz öncesi dönemde yüzde 70-80 düzeyinde seyreden borç yükü, kriz sonrasında hızla yükselmiş ve 2012 yılına gelindiğinde referans değerin iki katını aşan bir orana, yüzde 130 bandına çıkmıştır. Ülke, bütçe açıklarını kontrol altına almasına rağmen borç yükünün düşürülmesi hususunda arzulanan başarıyı gösterememiştir. Ülkedeki borç yükü halen olması gereken referans değerden oldukça uzaktır. (ii) Kriz öncesi dönemde borç yükünü yüzde 23'e kadar düşüren İrlanda, kriz döneminde borç yükünde sağladığı kazanımları koruyamamış ve ülkedeki borç yükü, her yıl misliyle artarak 2012 yılında yüzde 120 seviyesine çıkmıştır. Lakin sonrasında alınan mali konsolidasyon tedbirlerinin etkisiyle hem bütçe açıkları kontrol altına alınmış hem de borç yükü on yıl aradan sonra tekrar referans değere indirgenmiştir. PIIGS ülkeleri içinde İrlanda'nın sergilediği bu performans dikkat çekicidir. (iii) 2008 Kriziyle birlikte İtalya'nın borç yükü bakımından sergilediği performans daha da bozulmuş ve zaten yüzde 120 seviyesinde olan borç yükü, yüzde 140 seviyesine çıkmıştır. Bütçe açıklarını nispeten kontrol altında tutmayı başaran ülkenin borç yükünü kontrol altına alamamış olması, zaten var olan sorunun krizle birlikte artarak süre geldiğini gözler önüne sermiştir. (iv) Kriz öncesi dönemde borç yükü bakımından sorun yaşayan Yunanistan'ın sorunu daha da artmış ve ülkedeki borç yükü, -referans değerin üç katı olan- yüzde 180 bandına yükselmiştir. Öyle ki, kriz sonrası dönemde ülkenin bütçe açıklarını kontrol etmekteki başarısı, borç yükünü gerilemekte yetersiz kalmıştır. (v) İspanya'da kriz öncesi dönemde yüzde 35 düzeyine kadar düşürdügü borç yükünü koruyamamış, yaşanan krizle birlikte ülkedeki borç yükü, hızlı bir şekilde artarak yüzde 100 bandına yerleşmiştir.

Borç yükleri açısından bakıldığında PIIGS ülkelerinde karşımıza çıkan tablo oldukça endişe vericidir. Çünkü bütçe disiplini sağlanmış olmasına rağmen İrlanda dışındaki ülkelerin borç yükleri, referans değer olan yüzde 60'tan oldukça yüksektir. Alınan birçok tedbire rağmen borç yüklerinin azaltılamaması, PIIGS ülkelerindeki mali kırılganlık gerçeğini gözler önüne sermekte ve günümüz $A B^{\prime}$ sinde yaşanan yol ayrılıklarının esasta borç krizinden kaynaklandığını göstermektedir.

\section{SONUÇ VE DEĞERLENDIRME}

Soğuk Savaş'ın sona ermesiyle birlikte Avrupa Birliği yumuşak güce dayalı bir birlik etrafında kümelenen küresel bir çekim merkezi haline gelmiştir. Farklı sosyoekonomik yapıdaki ülkelerin bir araya gelmesiyle oluşturulan sinerji, bu gücün kaynağını oluşturmuştur. Lakin yaşanan krizler ile birlik bünyesinde yaşanan bazı ekonomik gelişmeler ve özellikle mali sorunlar sebebiyle $A B$, küresel ölçekte meydana gelen değişim ve dönüşüme yeterince uyum sağlayamamıştır.

AB' de hükümetler üstü yapının gelişimi çoğu kez ötelenmiş ve yaşanan sorunlara yönelik çözüm arayışları genellikle var olan hükümetler arası yapı tarafından şekillendirilmiştir. $A B^{\prime}$ de kurallar oluşturulmasına rağmen bu kurallara uygulanacak yaptırımların çoğu zaman uygulanmaması, hükümetler üstü yapının istenilen düzeyde çalışmadığının açık kanıtıdır. Örneğin 1993 yılında belirlenen Maastricht Yakınlaşma Kriterleri, tüm somutluğu ile ortadayken bazı üye devletler yeterli koşulları sağlamadıkları halde Parasal Birlik üyesi olmuş, Parasal Birlik üyesi olan bazı devletler ise şartları sağlayamaz hale geldiklerinde herhangi bir yaptırıma tabi tutulmamıştır. 1998 yılında imzalanan İstikrar ve Büyüme Paktı ile Parasal Birlik dışında kalan ülkelerin Euronun istikrarına zeval getirmeyen para ve maliye politikası uygulayacakları taahhüt altına alınmış, lakin taahhüdün yerine getirilmemesi halinde uygulanacak yaptırımlar belirsiz bırakılmıştır. Yine birliğin lokomotifi konumundaki Almanya ve Fransa'nın yakınlaşma kriterleri içindeki bütçe şartını 2002 ve 2003 yıllarında ihlal etmelerine yaptırım uygulanmaması Birliğin diğer ülkelerinin de kuralları ihlal etmelerine dayanak oluşturmuştur. Hal böyle olunca da kural ihlalleri meşruiyet kazanmış ve $A B$, kuralları olan lakin yaptırımları olmayan, olsa da uygulanmayan bir entegrasyona dönüşmüştür.

80 'li yıllarla birlikte "maliye politikası" uygulamaları adeta sansüre uğramış ve o dönemde ekonomi yönetimleri "para politikası" uygulamalarına yönelmiştir. Uzun süre para politikası uygulamaları ile yön verilen ekonomiler, 2008 küresel krizi ortaya çıktığında adeta bir kurtarıcı olarak maliye politikasına yönelmiştir. İzlenen mali istikrar programlarına yönelen ülke hükümetleri -aynen $70^{\prime} l i$ yıllarda olduğu gibi- büyük çaplı bütçe açıkları ve yüksek borç yükleri ile karşılaşmışlardır. Mali alanda yaşanan bu iki sorunun oluşmasında kriz sonucu iflasa sürüklenen şirketlerin kamulaştırma yoluyla kurtarılması, yani bir anlamda kapitalist zararın kamulaştırılması etkili olmuştur. Yaşanan kriz, 2010 sonrasında özellikle PIIGS ülkelerinde borç krizine dönüşünce hükümetler yakın geçmişte izledikleri genişletici politikaların bir anlamda maliyeti olan bütçe açıkları ve yükselen borç yüklerinin hafifletilmesi amacıyla sosyal kazanımları adeta tehdit eden "mali konsolidasyon" tedbirlerine yönelmiştir.

Tutarlardan da görüleceği üzere İtalya'nın borç yükü, diğer PIIGS ülkelerinin toplam borç stokundan her dönemde fazladır 
Krizle mücadelede öncelikle finansal kurtarma operasyonları ve sonrasında da iç talebi uyarıcı önlemlerin alınması, Birliğin zayıf halkasını oluşturan PIIGS ülkelerinin zaten düşük olan bütçe performanslarını daha da düşürmüş ve artan bütçe açıklarının finansmanında yine ve yeniden borçlanma yoluna gidilmiştir. Bu ülkelerin Parasal Birliğe girmeleri ile birlikte kredi dereceleri artmış, $A B$ ve Euro şemsiyesi altında kur risklerinin ortadan kalkması ile bu ülkelere olan sermaye akışı hızlanarak PIIGS ülkelerinin düşük faiz oranlarından borçlanmalarına imkan tanımıştır. PIIGS ülkelerinde yaşanan görece yüksek enflasyon, reel faiz oranının düşmesine hatta zaman zaman negatif değer almasına sebep olmuş, bu da borçlanmayı çok daha cazip hale getirmiştir. PIIGS ülkelerinin böylelikle kamu borç stokları yükselmiş ve yüksek borç yükü oluşan PIIGS ülkelerinde sürdürülebilirlik kaygıları arttığından bu ekonomilere duyulan güven sarsılmıştır. Kaldı ki, PIIGS ülkelerinde yaşanılan borç sorununun büyüklüğü, borçların ötelenerek çözülmesi ihtimalini zaten sıfırlamıştır. Ayrıca borç krizinin sürekli olarak kurtarma paketleri yoluyla çözülmeye çalışılması kredi riskinin yükselmesine ve ulusal seçmen kitlelerinin tepkilerine yol açmaktadır.

Seçmen tepkileri ulusal hükümetlerin tercihlerini etkilemekte ve Britanya örneğinde olduğu gibi çok daha radikal çözümlerin gündeme gelmesine sebep olmaktadır. Küresel bir şok olan 2008 krizi, AB içerisinde Birliğin ulus üstü yapısı ile ulusal hükümetler arasındaki çatışmayı belirginleşmiştir. Krizle beraber yaşanan Borç Krizi, Birliğin üçüncü büyük üyesi konumundaki Britanya'nın $A B^{\prime}$ den ayrılmasında başlıca etken olmuştur.

Küreselleşmenin şekil verdiği 21. Yüzyılda yaşanan krizler, sadece ticaret ve finans ilişkileri üzerinden değil, borç ilişkileri üzerinden de sirayet etkisi gösterecektir. 2008 Küresel Krizinin etkilerini yeni yeni atlatmaya başlayan PIIGS ülkeleri krizden borç yükleri artarak çıkmışlardır. 2019 yılının sonunda ortaya çıkan Covid 19 küresel salgını, tüm Dünya ülkeleri ile birlikte $A B$ özelinde özellikle i̇talya ve İspanya başta olmak üzere PIIGS ülkelerini vurmuştur. Mali kırılganlıkları yüksek olan PIIGS ülkelerinin yaşanacakları birer borç krizi, belki de $A B^{\prime}$ nin sonu olacak ve oluşturacağı sirayet etkisiyle tüm dünyaya yayılacaktır. Kaldı ki, Covid 19 küresel salgınının tüm dünyada sebep olduğu olumsuzluklar da tam tersi yönde $A B$ ülkelerini etkileyecektir. Bundan böyle oluşacak sorunların yakın geçmişte olduğu gibi $A B^{\prime}$ nde kurtarma paketleri ile geçiştirilmesi de mümkün değildir. Çünkü kamu maliyesi alanında yaşanan sorunlar PIIGS ülkelerinin dışındaki birçok AB ülkesi için de geçerlidir. Hal böyle olduğunda da zaten uzun yıllardır oluşturulamayan hükümetler üstü yapı yerine yine hükümetler arası yapı devreye girecek ve bizce ülkelerin yaşadıkları ve yaşayacakları borç krizleri, her bir hükümetin bağımsız olarak izledikleri mali politikalarla aşılmaya çalışılacaktır.

\section{KAYNAKLAR}

AB Bakanlığı (2011). Avrupa Birliği'nde Küresel Finansal Krize Karşı Alınan Önlemler ve Birliğin Rekabet Gücünün Artırılmasına Yönelik Girişimler: "Euro Rekabet Paktı". https://www.ab.gov.tr/siteimages/birimler/empb/yayinlar/euro plus pact.pdf

AB Konseyi (5 Temmuz 2004). Council Decision of 5 July 2004 on the existence of an excessive deficit in Greece (2004/917/EC). https://eurlex.europa.eu/legal-content/EN/TXT/?uri=uriserv:OJ.L .2004.389.01.0025.01.ENG

AB Konseyi (20 Eylül 2005a). Council Decision of 20 September 2005 on the existence of an excessive deficit in Portugal (2005/730/EC). https://eur-lex.europa.eu/legal-content/EN/TXT/?uri=uriserv:OJ.L .2005.274.01.0091.01.ENG

AB Konseyi (7 Ekim 2005). Council Recommendation with a view to bringing an end to the situation of an excessive government deficit in Portugal (12401/05). http://data.consilium.europa.eu/doc/document/ST-12401-2005-INIT/en/pdf

AB Konseyi (28 Temmuz 2005). Council Decision of 28 July 2005 on the existence of an excessive deficit in Italy (2005/694/EC). https://ec.europa.eu/economy finance/economic governance/sgp/pdf/30 edps/104-06 council/2005-07-28 it 104-6 council en.pdf

AB Konseyi (20 Eylül 2005b). Council Recommendation with a view to bringing an end to the situation of an excessive government deficit in Italy (11912/05). https://ec.europa.eu/economy finance/economic governance/sgp/pdf/30_edps/104-07_council/2005-07-28 it 1047 council en.pdf

AB Konseyi (27 Nisan 2009). Council Decision of 27 April 2009 on the existence of an excessive deficit in Spain (2009/417/EC). https://eurlex.europa.eu/legal-content/EN/TXT/?uri=uriserv:OJ.L .2009.135.01.0025.01.ENG

AB Konseyi (19 Ocak 2010a). Council Decision of 19 January 2010 on the existence of an excessive deficit in Portugal (2010/288/EC). https://eur-lex.europa.eu/legal-content/EN/TXT/?uri=uriserv:OJ.L .2010.125.01.0044.01.ENG

AB Konseyi (19 Ocak 2010b). Council Decision of 19 January 2010 on the existence of an excessive deficit in Italy (2010/286/EU). https://ec.europa.eu/economy finance/economic governance/sgp/pdf/30 edps/104-06 council/2009-12-02 it 126-6 council en.pdf

AB Komisyonu (2020a). Financial Assistance to Greece. https://ec.europa.eu/info/business-economy-euro/economic-and-fiscal-policycoordination/eu-financial-assistance/which-eu-countries-have-received-assistance/financial-assistance-greece_en\#first-programme-forgreece

AB Komisyonu (2020b). European Financial Stabilisation Mechanism (EFSM). https://ec.europa.eu/info/business-economy-euro/economicand-fiscal-policy-coordination/eu-financial-assistance/loan-programmes/european-financial-stabilisation-mechanism-efsm en 
AB Komisyonu (2020c). History of The Stability and Growth Pact. https://ec.europa.eu/info/business-economy-euro/economic-and-fiscalpolicy-coordination/eu-economic-governance-monitoring-prevention-correction/stability-and-growth-pact/history-stability-and-growthpact en\#1997).

AB Komisyonu (2020d). How the EU monitors national economic policies. https://ec.europa.eu/info/business-economy-euro/economic-andfiscal-policy-coordination/eu-economic-governance-monitoring-prevention-correction/how-eu-monitors-national-economic-policies en

Beker, V. A. (2014). The European Debt Crisis: Causes and Consequences., Journal of Stock \& Forex Trading. 3(2): 1-9. DOI: 10.4172/21689458.1000115

Bergsten, C. F. (2012). Why the Euro Will Survive. Foreign Affairs. 91(5): 16-22

Bölükbaş, M. T., Bölükbaş, M., Topal M. H. (2018). PIIGS Ülkeleri ve Türkiye'de Kamu BorçYükü Ile Ekonomik Büyüme Arasındaki ilişki. Londra, Current Debates in Social Sciences: Proceedings of CUDES 2018 September.

Dinan, D. (2008). Avrupa Birligi Tarihi. Çev. Hale Akay. İstanbul, Kitap Yayınevi.

Duman, Ö., S. (2017) The Political Economy of the Eurozone Crisis: Competitiveness and Financialization in PIIGS. Journal of Balkan and Near Eastern Studies. 20(3): 211-229. DOI: 10.1080/19448953.2018.1379752

Dünya Bankası (13 Şubat 2020). İstatistikler. https://data.worldbank.org/indicator/NY.GDP.MKTP.CD?locations=EU-US-CN

Eberhardt, M., Presbitero, A. F. (2015). Public debt and growth: Heterogeneity and non-linearity. Journal of International Economics, 97(1):45-58. https://doi.org/10.1016/j.jinteco.2015.04.005

ESM (30 Şubat 2020a.) Before the ESM. https://www.esm.europa.eu/efsf-overview

ESM (30 Şubat 2020b). About Us. https://www.esm.europa.eu/about-us

Eurostat (29 Ocak 2020). İstatistikler. https://ec.europa.eu/eurostat/data/database

Gogas, P. (13 Şubat 2011). The Proposed EU "Competitiveness Pact". https://businessthinker.com/the-proposed-e-u\%E2\%80\%9Ccompetitiveness-pact\%E2\%80\%9D/

Gümüş I., Tatlıyer M. (2013). Güney Avrupa Refah Rejimi'nin Borç Krizi. İ̧̧ Ahlakı Dergisi. 6(1): 1-37 DOI: 10.12711/tjbe.2013.6.1.0117

Kibritçioğlu A. (2011). Current Sovereign Debt Crisis in Eurozone Countries. Iktisat ve Toplum Dergisi. 10 (2011): 30-41. https://mpra.ub.unimuenchen.de/33528/1/MPRA paper 33528.pdf

Krugman, P. (2012). End this Depression Now! New York: Norton \& Company.

Öztürk, M. ve Aras, O.N. (2011). Euro ve Kriz Sonrası Dönemde Parasal İstikrar. Ekonomi Bilimleri Dergisi. 3 (2): 143-155. Retrieved from https://dergipark.org.tr/tr/pub/ebd/issue/4858/66832

TCTB (3 Ekim 2019). Yanıbaşımızdaki Dev Pazar Avrupa Birliği. https://www.ticaret.gov.tr/dis-iliskiler/avrupa-birligi/yani-basimizdaki-devpazar-avrupa-birligi

Samuel D. B. (2020). Assessing PIIGS Country Performance against Themselves and the EU. Asian Social Science 16(4):74-86. DOI: 10.5539/ass.v16n4p74

Siemiatkowski P., Jankowska E. (2013). Financial dependence of the PIIGS countries. Journal of World Economic Research. 2013; 2(5): 89-94 Published online November 10, 2013 (http://www.sciencepublishinggroup.com/i/jwer) doi: 10.11648/j.jwer.20130205.12

Şeker, H , Demirel, B , Eroğlu, I . (2016). EURO Bölgesi Borç Krizi Ve Ekonomik Büyüme iliş̧kisi. Balkan Sosyal Bilimler Dergisi. () , 446-457. Retrieved from https://dergipark.org.tr/tr/pub/bsbd/issue/43860/539502

Uygur, E. (2001). Enflasyon, Para ve Mali Baski: iktisat Politikasında Geri Kalmışlık. Iktisat, İşletme ve Finans Dergisi. 16 (189): 7-23. DOI: 10.3848/iif.2001.189.9788

World Government Bonds (2 Mart 2020). Credit Ratings. http://worldgovernmentbonds.com

YIImaz, B. (2013). Reflections of The Global Economic Crisis on The Countries of PIIGS And Turkey's Macroeconomic Variables. Marmara Üniversitesi iktisadi ve Idari Bilimler Dergisi. 34 (1): 229-252. Retrieved from https://dergipark.org.tr/tr/pub/muiibd/issue/497/4417 